\title{
Enhancing the Quality and Relevance of Higher Education Through Effective Teaching Practices and Instructors' Characteristics
}

\author{
Birhanu Moges Alemu \\ Department of Psychology, School of Educational Science and Technology Teachers Education, \\ Adama Science and Technology University \\ *Corresponding Author: abirhanumoges@yahoo.com
}

Copyright $(0) 2014$ Horizon Research Publishing All rights reserved.

\begin{abstract}
The five key behaviours for effective teaching are: lesson clarity, instructional variety, and instructor task orientation, engagement in the learning process and student success rate. This study examines the reflections of university students and instructors regarding the implementation of effective teaching practices and instructors' characteristics in engineering education. Data gathered from two groups (engineering students \& instructors) interviews were developed and 25 item Likert scale questionnaires were completed by a sample of 69 students and 64 instructors. Means, ranking, and standard deviation followed by other analyses indicated that there was a high degree of similarity between students and instructors with respect to the perceived attributes of effective and ineffective teaching. It appears that the effective instructors are the mirror image of the ineffective by being imbued with a generous dose of personality traits in addition to skills. Both instructors and students in this research conducted in the selected universities of Ethiopia depicted the effective/excellent university instructor as someone who: (1) is respectful, (2) makes classes interesting, (3) is fair in evaluating, (4) cares about students' success, (5) shows a love for their subject, (6) is friendly, (7) encourages questions and discussion, (8) is always well prepared and organized, and (9) makes difficult subjects easy to learn. Findings of students' and instructors' perspectives suggest that effective teaching is the blending of both personality and ability factors. The key factor, however, remains the instructors' personality.
\end{abstract}

Keywords Effective Teaching, Instructors' Characteristics, Engineering Education, Universities

\section{Introduction}

Effective teaching is an art and no easy endeavour. Recent findings shed light on two characteristics of effective instructor: their personality and their ability. From the personality perspective, an effective university level instructor is one who demonstrates "... closeness, warmth, and enthusiasm (immediacy) ... perceived physical and psychological closeness of the instructor to the student ..." (Walls, Nardi, Minden \& Hoffman, 2002). From the ability perspective, the crucial factors of the effective instructor are being skilled, knowledgeable and experienced (Beishuizen, Hof, Putten, Bouwmeester \& Asscher, 2001). Effective instructors know how to create an effective learning environment by being organized, prepared, and clear (Barnes, Lock, 2010; Oredbeyen, 2010; Walls, et al., 2002).

There appears to be few studies that have been purposely designed to examine effective teaching characteristics from the perceptions of those who receive and those who deliver university level teaching. Witcher, Onwuegbuzie and Minor (2001) help to make this point when they write: "Although the literature abounds with information regarding instructor effectiveness, the majority of these studies do not represent primary studies". The researcher has come across students' complaints about their instructors being ineffective. Heads of departments and schools deans have received anonymous applications from students complaining about ineffective instructors. Some cases of low throughput rate could possibly be attributed to these complaints of instructor ineffectiveness by students. University instructors are often heard expressing those students and instructors differ in their views of what constitutes effective instructors/teaching. The need for this study arises from a professional desire to better serve students and communities. It has been researcher observation while working with different levels of students at different institutes in the high schools, teacher training institutions, college and university that some instructors interface very well with their students and are highly successful in contributing to their profession, while others appear to have difficulties in the classroom from the initial contact with students. Therefore, the main intent of this study was to analysis implementation of effective teaching practices and instructors' characteristics in engineering education at selected universities, Ethiopia. To achieve this main goal, the present study addresses the 
following basic research questions:

1. What are the predominant characteristics used by the study participants to describe effective teaching?

2. To what extent are student perceptions of effective teaching similar to those of instructors?

3. To what extent are student perceptions of ineffective teaching similar to those of instructors?

4. Are the descriptors used to describe effective teaching amongst the two sample groups focused more on the ability or on the personality view?

5. To what extent do mediating factors such as academic discipline and participants' gender have an effect on the portrait of the effective/excellent instructor?

Objectives of the study: On line of the basic questions, this study attempts to achieve the following objectives:

- $\quad$ explore the relationship between effective teaching and the instructor's personality and ability;

- assess students' and instructors' perceptions of effective teaching practices;

- examine predominant instructors' characteristics perceived by the study participants to describe effective teaching,

- identify whether instructor's characteristics had any effects on effective teaching;

- $\quad$ provide useful information to instructors on teaching approaches and instructor characteristics that affect effective teaching.

Significance of the Study: The results obtained and implications drawn could be of benefit to instructors elsewhere who are receiving students from all corners of the country, to better understand student needs from another culture in the classroom environment. Specifically, this study has great educational implication at college and university level teaching-learning practice. In addition, researcher sees this work as a contribution to help guide those who are involved in the development of future research on similar settings. In view of the above, this study will help university instructors, students, academic department heads, deans, the Ministry of Education, the Regional Education Bureau and other concerned bodies to design preventive, intervention and rehabilitative measures regarding problems related to the direct influence of the implementation of effective teaching practices and instructors' characteristics in engineering education.

\section{Materials and Methods}

In this study, the underlying belief is that mixed methods research intentionally engages a multiple set of approaches; all approaches are valuable and have something to contribute to understanding, but only partially. Hence, a mixed-method approach using a survey design for obtaining descriptive statistics supported by a qualitative investigation was employed because of the complexity of the research issues. The researcher for this particular study primarily selected descriptive survey method because it is found to be the most appropriate technique for collecting vast information and opinions from quit a large number of respondents.

Sources of data: The primary sources included in this study were students and instructors, deans and vice deans, and department heads selected from four sample universities. The secondary sources for the present study were printed materials. The four universities (Adama, Addis Ababa, Haramaya \& Hawasa) instructors and senior students were selected from a total of engineering universities in Ethiopia.One-tenth of the senior year engineering students from each sample university were selected by using systematic and random sampling technique.

Data collectioninstruments: In order to collect the required information the researcher was used questionnaires, interviews and observation check list. The interview instrument was developed by researcher and has been used extensively in his study. The questionnaire containing mainly closed ended items were administered to instructors and students. These respondents were responded to different items concerning the implementation of effective teaching practices and instructors' characteristics in the light of effective teaching -learning in the sample universities, Ethiopia. The observation checklist was helped the researcher to observe the extent to which the universityinstructors' use different teaching methods effectively. The questionnaire was implemented a Likert Scale of response of 1 to 4 with the following meanings: $1=$ Least Important, 2= Somewhat Important, 3= Important, $4=$ Very Important. Interview and observation was used to triangulate information collected through questionnaire.

Methods of data analysis: The data collected through different instruments (questionnaires, observation and interview) were organized, presented in tables and then analyzed statistically using statistical methods such as percentages, means, standard deviation and Ch-square and were interpreted.

\section{Results and Discussion}

The research questions identified in the introduction the focal point for this were study. The findings revealed from three sources: statistical analysis of the questionnaire items, recorded interviews and the open-ended questionnaire items, and it was discussed the findings relevant to the literature reviewed.

Research question one: What are the predominant characteristics used by the study participants to describe effective teaching? Since the questionnaire items were categorized under two separate categories of effective teaching characteristics (personality and ability/skill), the results from the questionnaire are presented in two different Tables (1 and 2) and was addressed in separate sub-sections. From Table .1 below, results from the questionnaire data indicate that according to the sample respondents, the 
following six personality characteristics were very important (VI) to describe effective teaching: are respectful of their students; make classes interesting; are fair in grading and evaluating student work; care about students succeeding in their course; show that they really like the subject they teach, and are friendly to students. Also worthy of mention is that all remaining personality characteristics included in the questionnaire survey instrument were considered by the study respondents to be important (I) descriptors of effective teaching. Thus, each one of the 11 personality characteristics specifically designed for the questionnaire was rated as either very important or important. This indicates that all personality characteristics reflected in the questionnaire were essential (average mean of 3.37, Table.1) to the entire sample population to describe effective/excellent teaching, and should be considered by instructor interested in demonstrating to their students that they have effective teaching skills.

According to the two population groups (students \& instructors) in this study, the most important characteristic of the effective instructor to emerge is the personality trait "are respectful to their students" (mean 3.73, Table 1). This finding closely matches the high (second place) ranking of Feldman's trait "is concerned with, is friendly to and respectsstudents" and matches the results from studies conducted to other researchers (Saafin, 2005 \& Raymond, 2001). As it has seen in the literature review, other researchers also report that instructors must demonstrate respect for their students from the moment of first encounter for effective teaching to transpire (Barnes, Lock, 2010; Day, 2004 \& Hay McBer, 2000). Respect for students emerged as $9^{\text {th }}$ highest trait to be mentioned in the qualitative, open-ended portion of the questionnaire instrument (Table 2 below ).

Upon closer examination of Table 2, it appears that respect for students is more of a concern for instructor respondents. Instructor respondents in particular mentioned this trait frequently; in addition to delivering content knowledge, also prepare university students by inculcating in them the social behavioural skills such as respect for self, others, their instructors, and institutional policies and procedures. "Creating an environment that is mutually respectful is the most important thing that effective/excellent instructors can do" is how one instructor respondent answered this open-ended question on the questionnaire. The second highest overall rated effective personality teaching trait as revealed by this study's respondents is the descriptor "makes classes interesting" (mean 3.70, Table1). This trait ranked high in both components of this study (questionnaire results, and openended questions). "Make classes interesting and fun" was the most frequently mentioned trait mentioned in the openended question (Table 2), providing further support as to the importance of this finding. "An effective instructor should regularly succeed in inculcating a love of knowledge" are the words written by one instructor while answering the open-ended question on the survey instrument. Being "fair in grading and evaluating student work" was the third most prominent effective teaching characteristic as reported by respondents. Instructors rated this trait as their most important descriptor of effective/excellent teaching while students rated it $5^{\text {th }}$. This suggests that instructors at the university where the study was conducted have high ethical standards. Fairness in grading and evaluating student work rated not as high in the literature review $\left(5^{\text {th }}\right.$ overall) as it did in the current study, but the importance of objectivity to effective teaching has been discussed methodically in the literature reviewed (Barnes, Lock, 2010; Beishuizen et al.,2001; Day, 2004; Oredbeyen, 2010; Raymond, 2001; Saafin, 2005)

Table 1. Descriptive statistics of the personality traits measure of effective teaching by entire sample $(\alpha=0.05)$

\begin{tabular}{|c|c|c|c|c|c|c|}
\hline Personality characteristics & Min & Max & Mean & Rate & S D & Rank \\
\hline$\ldots$ are respectful of their students. & 1 & 4 & 3.73 & VI & .538 & 1 \\
\hline .... make classes interesting. & 1 & 4 & 3.70 & VI & .522 & 2 \\
\hline .... are fair in grading and evaluating student work & 1 & 4 & 3.67 & VI & .612 & 3 \\
\hline .... care about students succeeding in their course. & 1 & 4 & 3.56 & VI & .632 & 4 \\
\hline .... show that they really like the subject they teach. & 1 & 4 & 3.53 & VI & .713 & 5 \\
\hline$\ldots$ are friendly to students. & 1 & 4 & 3.50 & VI & .735 & 6 \\
\hline .... welcome students' opinions/ suggestions. & 1 & 4 & 3.38 & I & .682 & 7 \\
\hline .... are available to help students outside of class. & 2 & 4 & 3.33 & I & .693 & 8 \\
\hline .... use humour in the classroom. & 1 & 4 & 3.33 & I & .781 & 9.5 \\
\hline .... make an effort to get to know their students. & 1 & 4 & 3.11 & I & .794 & 9.5 \\
\hline .... have a unique teaching style. & 1 & 4 & 3.11 & I & .049 & 11 \\
\hline \multicolumn{3}{|l|}{ Average of means } & 3.37 & & & \\
\hline
\end{tabular}


Table 2. Characteristics of effective instructors extracted from open-ended questions and rank ordered

\begin{tabular}{|c|c|c|c|c|}
\hline VERB REFERENT STATEMENTS & Students & Instructors & Sum & Rank \\
\hline 1. Makes class interesting/fun & 25 & 25 & 50 & 1 \\
\hline 2. Is friendly to students & 26 & 12 & 37 & 2 \\
\hline 3. Really knows subject knowledge & 7 & 20 & 27 & 3 \\
\hline 4. Cares about students' learning & 9 & 24 & 25 & 4 \\
\hline 5. Makes lessons understandable & 12 & 10 & 22 & 5 \\
\hline 6. Is well prepared for class & 8 & 10 & 18 & 6 \\
\hline 7. Is enthusiastic & 5 & 12 & 17 & 7 \\
\hline 8. Encourages students to think & 2 & 14 & 16 & 8 \\
\hline 9. Respects students & 4 & 10 & 14 & 9 \\
\hline 10. Has good teaching style & 9 & 21 & 10 & 5 \\
\hline 11. Understands how students think and feel & 3 & 10 & 13 & 10.5 \\
\hline 12. Gives support & 8 & 3 & 11 & 12 \\
\hline 13. Is approachable/available & 3 & 7 & 10 & 13 \\
\hline 14. Is fair & 1 & 5 & 9 & 14 \\
\hline 15. Has good sense of humour & 5 & 2 & 7 & 15.5 \\
\hline 16. Listens to students' questions \& opinions & 5 & 2 & 7 & 15.5 \\
\hline 17. Relates theory to outside world & 1 & 5 & 6 & 17.5 \\
\hline 18. Is professional & 1 & 4 & 6 & 17.5 \\
\hline 19. Has lots of experience & 6 & 0 & 6 & 17.5 \\
\hline 20. Is adaptable/flexible & 1 & 4 & 5 & 20 \\
\hline 21. Is patient & 3 & 1 & 4 & 21.5 \\
\hline 22. Develops new activities all the time & 2 & 2 & 4 & 21.5 \\
\hline 23. Makes students think & 0 & 3 & 3 & 23.5 \\
\hline 24. Is kind & 2 & 1 & 3 & 23.5 \\
\hline 25. Develops students' skills & 0 & 2 & 2 & 25.5 \\
\hline & \multicolumn{2}{|c|}{ Total sum } & 332 & \\
\hline
\end{tabular}

Note: italicized bold text indicates Personality factors; non-highlighted text indicates Ability/skill factors.

Ability characteristics $\quad 94 \quad 28 \%$

$\begin{array}{llllll}\text { Personality characteristics } & 238 & \mathbf{7 2} \% & \text { Sum } & 332 & 100 \%\end{array}$
The fourth highest rated personality characteristic of effective teaching to emerge from this study was "caring about students succeeding in their course" and was also ranked fourth highest according to the open-ended question on the survey instrument (Table 2). Students ranked this trait as their second most important indicator of teaching excellence. Conversely, instructors rated this trait higher ( $3^{\text {rd }}$ overall). This trait of genuinely caring for students' success was also important to researchers examined in this study (Beishuizen et al., 2001; Day, 2004; Hay McBer, 2000; Saafin, 2005; Walls etal., 2002). Making a link between this study's results and the literature, Borich (2000:27) describes effective instructors as those who “... provide a warm and encouraging classroom climate by letting students know help is available". The essence of this characteristic of effective teaching is captured by the simple words one student used to describe effective instructors in the open ended question: "To actually care about their students". The last predominant (very important) personality attribute of effective teaching that emerged from the study respondents was the characteristic "are friendly to students". This 6th highest ranked personality trait (mean 3.50, Table 1) was placed 3rd highest by the students and occupied 7th position according to the instructors. Following on from the previous findings, students rated this trait as their premier characteristic, while the more experienced, more independent students ranked this item $6^{\text {th }}$ of the eleven personality characteristics measured in the questionnaire. A comparison of how students and instructor rated the eleven personality characteristics contained in the questionnaire instrument can be reviewed in Table 3 .

Of the eleven personality traits included in the survey instrument, six were rated as very important(dominant) and five were rated as important descriptors of the effective instructor. This high ranking of each of the eleven personality characteristics included in the survey instrument provides further verification as to the cultural appropriateness of the survey instrument. Though it can be 
seen that there are some minor differences in opinion between how students and instructors rated the personality traits included in the questionnaire instrument, it is evident that there is substantial agreement between students and instructors views as to which traits are deemed important to effective teaching. This study findings reveal that instructors who demonstrate genuine respect for their students, make classes interesting and exciting places to be, are fair in all students' dealings, care about students' success, genuinely enjoy teaching their subject matter and are always friendly and approachable are more likely to be effective in transferring knowledge to their students, and in return more likely to be rated higher in instructor evaluations. According to the student and instructor respondents, three ability attributes emerged as dominant (very important) by the study participants to describe effective/excellent teaching: encourage students' questions and discussion; are always well prepared and organized, and make difficult subjects easy to learn.

Table 3. Descriptive statistics used to compare students and instructors perspectives on the importance of personality characteristics of effective/excellent instructors

\begin{tabular}{|c|c|c|c|c|c|c|c|c|c|c|}
\hline \multirow[b]{2}{*}{ Personality characteristics } & \multicolumn{5}{|c|}{ Students } & \multicolumn{5}{|c|}{ Instructors } \\
\hline & Min & Max & Mean & Rate & Rank & Min & Max & Mean & Rate & Rank \\
\hline ... make classes interesting. & 2 & 4 & 3.7 & VI & 1.5 & 1 & 4 & 3.7 & VI & 3 \\
\hline$\ldots$ are respectful of their students. & 2 & 4 & 3.7 & VI & 1.5 & 1 & 4 & 3.8 & VI & 2 \\
\hline$\ldots$ are friendly to students. & 1 & 4 & 3.6 & VI & 3 & 2 & 4 & 3.4 & I & 7 \\
\hline ...care about students succeeding in their course. & 1 & 4 & 3.5 & VI & 4 & 1 & 4 & 3.6 & VI & 4 \\
\hline ... show that they really like the subject they teach. & 1 & 4 & 3.5 & I & 5.5 & 2 & 4 & 3.6 & VI & 5 \\
\hline ... are fair in grading and evaluating student work. & 1 & 4 & 3.5 & I & 5.5 & 3 & 4 & 3.9 & VI & 1 \\
\hline ... are available to help students outside of class. & 2 & 4 & 3.4 & I & 7 & 4 & 2 & 3.3 & I & 8 \\
\hline ...welcome students' opinions/ suggestions. & 2 & 4 & 3.4 & I & 8 & 1 & 4 & 3.4 & I & 6 \\
\hline ... make an effort to get to know their students. & 1 & 4 & 3.1 & I & 9 & 2 & 4 & 3.1 & I & 10 \\
\hline ... have a unique teaching style. & 1 & 4 & 3.1 & $\mathrm{I}$ & 10 & 1 & 4 & 1.9 & SI & 11 \\
\hline ... use humour in the classroom. & 1 & 4 & 3.0 & $\mathrm{I}$ & 11 & 2 & 4 & 3.3 & $\mathrm{I}$ & 9 \\
\hline \multicolumn{6}{|c|}{ Average of means 3.39} & \multicolumn{4}{|c|}{ Average of means 3.34} & \\
\hline
\end{tabular}

Table 4. Descriptive statistics of the ability characteristics measure of effective teaching by entire sample $(\alpha=0.05)$

\begin{tabular}{|c|c|c|c|c|c|c|}
\hline Ability characteristics & Min & Max & Mean & Rate & S D & Rank \\
\hline .... encourage students' questions and discussion. & 1 & 4 & 3.7 & VI & .62 & 1 \\
\hline$\ldots$ are always well prepared and organized. & 2 & 4 & 3.6 & VI & .62 & 2 \\
\hline ... make difficult subjects easy to learn. & 1 & 4 & 3.5 & VI & .69 & 3 \\
\hline ... have expert, up-to-date knowledge of their subject. & 1 & 4 & 3.4 & I & .73 & 4 \\
\hline ... expect students to become independent learners. & 1 & 4 & 3.3 & $\mathrm{I}$ & .73 & 6 \\
\hline ... give frequent feedback about student progress. & 1 & 4 & 3.2 & $\mathrm{I}$ & .71 & 7 \\
\hline ... encourage students to learn in pairs/groups. & 1 & 4 & 3.0 & I & .89 & 8 \\
\hline ... maintain strict control over the class. & 1 & 4 & 2.8 & I & .78 & 9 \\
\hline ... give many quizzes and tests. & 1 & 4 & 2.3 & SI & .81 & 11 \\
\hline ... have many years of teaching experience. & 1 & 4 & 2.2 & SI & .96 & 12 \\
\hline ... assign a lot of homework. & 1 & 4 & 2.0 & SI & .74 & 13 \\
\hline ... lecture (talk) for the entire class period. & 1 & 4 & 1.7 & SI & .87 & 14 \\
\hline \multicolumn{3}{|c|}{ Average of means } & 2.89 & & & \\
\hline
\end{tabular}


Table 4 above, indicates that three ability attributes were considered to be very important descriptors of effective instructors to the entire sample and that the highest ranked ability trait used to define effective/ excellent teaching emerged as "encourage students' questions and discussion". Overall, this ranked the 4th highest of all questionnaire personality and ability characteristics with a mean of 3.65 . What was unexpectedly discovered is that instructors rated this measure as their most important ability characteristic. This characteristic (is open to students' ideas, opinions, and discussion) also rated high in the literature summary, tying for second place overall (Saafin, 2005; Walls et al., 2002; Beishuizen et al., 2001). The second of three predominant ability attributes viewed as very important by the study respondents is the descriptor of instructors who "are always well prepared and organized" (Table 4). Rated 5th highest of the 25 teaching characteristics examined through statistical analysis, (mean 3.57), being prepared and organized also rated very high in the literature review (3rd place) and was discussed by earlier researchers (Saafin, 2005; Walls et al., 2002). Results from the open-ended question also indicate the importance of instructors being prepared to stand and deliver well-organized materials and lessons to their students $\left(6^{\text {th }}\right.$ position, Table 2$)$. In answering the interview question, "Twenty years from now, what do you think you will remember the most from your best university instructor?, one student respondent seized this opportunity to help us realize the importance of this trait from learners' perspectives: "... how he interacts with his students and was always prepared for class." The last predominant effective teaching ability attribute to emerge from this study was the aptitude of instructors to make difficult subjects easy to learn (Table4). This characteristic, like all others discussed while answering this first research question, appears to be common as well. The literature review meta-table ranks this as $4^{\text {th }}$ most important ("explains using simple terms") and was important to preceding researchers (Walls et al., 2002; Beishuizen et al., 2001). A comparison between how students and instructor rated the eleven ability characteristics found in the questionnaire instrument is presented in Table 5.

It is evident from Table 5 that a high degree of similarity has been expressed in the views of student and instructors on the importance of the ability attributes included in the survey instrument. It can be observed in Table 5 mean value of items $(. \ldots$ are always well prepared and organized; ... have expert, up-to-date knowledge; ... give frequent feedback progress; ... maintain strict control over the class; and ... lecture (talk) for the entire class period) have expressed by both respondents( students \& instructors) in similar way.

Table 5. Descriptive statistics used to compare student and instructor on the importance of ability characteristics of excellent instructors- open-ended question

\begin{tabular}{|c|c|c|c|c|c|c|c|c|c|c|}
\hline \multirow[b]{2}{*}{ Ability characteristics } & \multicolumn{5}{|c|}{ Students } & \multicolumn{5}{|c|}{ Instructors } \\
\hline & Min & Max & Mean & Rate & Rank & Min & Max & Mean & Rate & Rank \\
\hline $\begin{array}{c}\ldots . . \text { are always well prepared and } \\
\text { organized. }\end{array}$ & 2 & 4 & 3.6 & VI & 1 & 2 & 4 & 3.6 & VI & 1 \\
\hline $\begin{array}{l}\text {... make difficult subjects easy to } \\
\text { learn. }\end{array}$ & 2 & 4 & 3.5 & VI & 2 & 1 & 4 & 5.6 & VI & 2 \\
\hline $\begin{array}{c}\ldots \text { have many years of teaching } \\
\text { experience. }\end{array}$ & 1 & 4 & 2.5 & I & 3 & 1 & 4 & 1.8 & VI & 3 \\
\hline $\begin{array}{l}\text {... encourage students' questions } \\
\text { discussion. }\end{array}$ & 1 & 4 & 3.4 & I & 4 & 1 & 4 & 3.9 & VI & 4 \\
\hline ... have expert, up-to-date knowledge. & 1 & 4 & 3.4 & I & 5 & 1 & 4 & 3.4 & I & 5 \\
\hline ... require students to think critically. & 1 & 4 & 3.2 & I & 6 & 2 & 4 & 3.6 & VI & 6 \\
\hline ... give frequent feedback progress. & 1 & 4 & 3.1 & I & 7 & 2 & 4 & 3.3 & I & 7 \\
\hline $\begin{array}{l}\text {.... expect students to become } \\
\text { independent. }\end{array}$ & 1 & 4 & 3.1 & I & 8 & 2 & 4 & 3.5 & I & 8 \\
\hline $\begin{array}{c}\text {... maintain strict control over the } \\
\text { class. }\end{array}$ & 1 & 4 & 2.9 & I & 9 & 1 & 4 & 2.7 & I & 9 \\
\hline $\begin{array}{l}\text {... encourage students to learn in } \\
\text { pairs/groups. }\end{array}$ & 1 & 4 & 2.9 & I & 10 & 1 & 4 & 3.1 & I & 10 \\
\hline $\begin{array}{l}\ldots \text { use the latest computer technology } \\
\text { in their teaching. }\end{array}$ & 1 & 4 & 2.8 & I & 11 & 1 & 4 & 2.2 & SI & 11 \\
\hline$\ldots$ give many quizzes and tests. & 1 & 4 & 2.6 & I & 12 & 1 & 4 & 2.1 & SI & 12 \\
\hline $\begin{array}{l}\ldots . \text { lecture (talk) for the entire class } \\
\text { period. }\end{array}$ & 1 & 4 & 2.2 & SI & 13 & 1 & 4 & 2.1 & NI & 13 \\
\hline ... assign a lot of homework. & 1 & 4 & 2.1 & SI & 14 & 1 & 4 & 1.9 & SI & 14 \\
\hline \multicolumn{3}{|l|}{ Average of means } & 2.95 & \multicolumn{4}{|c|}{ Average of means } & 2.82 & & \\
\hline
\end{tabular}


Research question two: To what extent are student perceptions of effective teaching similar to those of instructors? Even though numerous matches appeared amongst the respondents in regards to effective teaching, some minor mismatches did surface. In other words, what the participating students appeared to value in their instructors differed in some instances from what the participating instructors seemed to regard as very important to teaching effective. Table 6 below indicates the major matches of personality and ability factors between students and instructors unveiled in this study to describe the effective instructor.

Table 6. Major matches between instructors and students in descriptors used to describe effective teaching

\begin{tabular}{|c|c|}
\hline Personality Traits & Ability Characteristics \\
\hline $\begin{array}{c}\text { Are respectful of their } \\
\text { students }\end{array}$ & $\begin{array}{c}\text { Encourage students' questions and } \\
\text { discussion }\end{array}$ \\
\hline Make classes interesting & $\begin{array}{c}\text { Are always well-prepared and } \\
\text { organized }\end{array}$ \\
\hline $\begin{array}{c}\text { Care about students } \\
\text { succeeding in their course }\end{array}$ & Make difficult subjects easy to learn \\
\hline $\begin{array}{c}\text { Show that they really like } \\
\text { the subject they teach }\end{array}$ & \\
\hline Are friendly to students & \\
\hline
\end{tabular}

Table 7. Major mismatches between instructors and students in descriptors used to describe effective teaching

\begin{tabular}{|c|c|}
\hline Personality Traits & Ability Characteristics \\
\hline $\begin{array}{c}\text { Have a unique teaching style, } \\
\text { give many quizzes and tests }\end{array}$ & $\begin{array}{c}\text { Use the latest computer technology } \\
\text { in their teaching }\end{array}$ \\
\hline $\begin{array}{c}\text { Are fair in grading and } \\
\text { evaluating student work }\end{array}$ & Underlined text = students' views \\
\hline \multirow{4}{*}{$\begin{array}{c}\text { Underlined text }=\text { students' } \\
\text { views }\end{array}$} & Bold text = instructor views \\
\cline { 2 - 2 } Bold text = instructor views & $\begin{array}{c}\text { Have many years of teaching } \\
\text { experience }\end{array}$ \\
\cline { 2 - 2 } & $\begin{array}{c}\text { Encourage students' questions and } \\
\text { discussion }\end{array}$ \\
\cline { 2 - 2 } & $\begin{array}{c}\text { Expect students to become } \\
\text { independent learners }\end{array}$ \\
\hline
\end{tabular}

Participating students and instructors agreed on a number of characteristics they believed distinguished between the effective and ineffective university instructor. Both students and instructors regarded highly as very important (VI) the quality to treat students with respect and caring. The participating instructors' and students' perceptions also matched with regard to making classes interesting, caring about their students' success, demonstrating a love for teaching and being friendly. In addition to the five personality characteristics listed above, three ability characteristics were also stressed as being very important
(VI) to all participants: encouraging students' questions, being well-prepared and organized and having a knack for making difficult subjects understandable. Thus, according to these study participants, both skills and affective factors are necessary virtues to paint a portrait of the effective university instructor. By referring to data in Table 7, it can be seen that four characteristics were considered by students to be more important than instructors (bold text) in this study.

Differences in opinions between the instructor and student groups occur when the mean difference is greater than 0.30. Student results indicate that having a unique teaching style, giving a lot of tests, using the latest computer technology and having many years of teaching experience was more important than it was to instructors. Students who express the view that each instructor should have his or her own style are possibly a reflection upon the inexperience of the undergraduate student participants in this survey who perhaps feel that instructor have the responsibility to perform entertaining lectures and classes for them. Similarly, a student indicating that they would prefer an instructor who gives them lots of tests suggests that students are looking for personal feedback and practice opportunities, rather than being graded for the entire semester by one final exam. Students also rated instructors who use computer technology as more important than did the instructors themselves possibly reflects that the former are more attuned to the latest developments in computer technology than their instructors who are possibly using all their spare time preparing lectures, examinations and demands for teaching portfolios placed upon them.

Table 8 below, represents personality findings extracted from the data and is presented to explain similarities between students and instructors on personality characteristics of effective teaching. Many similarities can be observed between the students and instructors of this study conducted in the selected universities, Ethiopia. Both groups (students and instructors) consider making classes interesting, being respectful of students and caring about students' success to be very important (VI) or predominant characteristics of effective teaching. Furthermore, both student and instructor respondents share the perception that effective teaching is exhibited by instructors who remain available to students outside of class, who are open to students' input, make an effort to learn their students' names and who employ appropriate humour in the classroom. Three other personality items - being friendly to students, demonstrating that they like their subject and being fair when dealing with students - were also considered as either important or very important to both groups. 
Table 8. Student and instructor overall ratings of personality characteristics of effective teaching

\begin{tabular}{|c|c|c|}
\hline Personality characteristics of excellent teaching & Student rating & Instructor rating \\
\hline Make classes interesting & VI & VI \\
\hline Are respectful of their students & VI & VI \\
\hline Are friendly to students & VI & I \\
\hline Care about students succeeding in their course & VI & VI \\
\hline Show that they really like the subject they teach & I & VI \\
\hline Are fair in grading and evaluating student work & I & VI \\
\hline Are available to help students outside of class & I & I \\
\hline Welcome students' opinions/suggestions & I & I \\
\hline Make an effort to get to know their students & I & I \\
\hline Have a unique teaching style & I & SI \\
\hline Use humour in the classroom & I & I \\
\hline
\end{tabular}

Table 9. Student and instructor overall ratings of ability characteristics of effective teaching

\begin{tabular}{|c|c|c|}
\hline Ability characteristics of excellent teaching & Student rating & Instructor rating \\
\hline Are always well prepared and organized & VI & VI \\
\hline Make difficult subjects easy to learn & VI & SI \\
\hline Have many years of teaching experience & I & VI \\
\hline Encourage students' questions and discussion & I & I \\
\hline Have expert, up-to-date knowledge of their subject & I & VI \\
\hline Require students to think critically & I & I \\
\hline Give frequent feedback about student progress & I & I \\
\hline Expect students to become independent learners & I & I \\
\hline Maintain strict control over the class & I & SI \\
\hline Encourage students to learn in pairs/groups I & I & SI \\
\hline Use the latest computer technology in their teaching & I & I \\
\hline Give many quizzes and tests & SI & NI \\
\hline Lecture (talk) for the entire class period & SI & SI \\
\hline Assign a lot of homework & & \\
\hline
\end{tabular}

Table 9 above, represents the findings extracted from the data and are presented to explain similarities between students and instructors on the ability characteristics of effective teaching. As found with personality traits, considerable overlap exists between how students and instructors of this study conducted at selected universities in the Ethiopia view ability characteristics of effective teaching. Both groups (students \& instructors) consider effective instructors to be always well prepared for their classes and have the ability to make difficult topics easy to learn. Despite this finding, however, it can be reasonably concluded that student and instructors perceptions of what constitutes effective teaching are to a large extent very similar. Other sub-group differences which have emerged will be discussed below.

A comparison of the significant differences between the students and instructors indicates once again somewhat different views between the two groups (it can be seen from Table 9 above). Instructors rated six ability characteristics to be more important indicators of effective teaching than did their students. Instructors would more likely describe the effective instructor as one who requires students to think critically, encourages students to work in small groups or in pairs, gets to know their students, and encourages students' discussion and questions. Students, on the other hand, would place more emphasis on ability descriptors of effective instructors such as being current with the latest technology and up-to-date with their subject knowledge.

Research question three: To what extent are student perceptions of ineffective teaching similar to those of instructor?

To answer this question, descriptive data that was collected through interviews and respondents' answers to an open-ended question of the questionnaire asking them to describe in their own words the ineffective instructor was compared. The numbers in the columns in Table 10 above indicate the number of times each verb referent statement was referred from the open-ended question (O) asking respondents to state in their own words the most striking characteristics of the ineffective/worst university instructors 
Table 10. Student and instructor perceptions of ineffective teaching extracted from interviews and open-ended question $(\mathrm{O})$

\begin{tabular}{|c|c|c|c|c|}
\hline \multirow{2}{*}{ Verb-referent statements } & \multicolumn{2}{|c|}{ Students } & \multicolumn{2}{c|}{ Instructors } \\
\cline { 2 - 5 } & $\mathrm{I}$ & $\mathrm{O}$ & $\mathrm{I}$ & $\mathrm{O}$ \\
\hline Is disrespectful of students & 22 & 14 & 5 & 13 \\
\hline Doesn't care if students understand & 10 & 12 & 15 & 30 \\
\hline Is boring & 13 & 7 & 10 & 13 \\
\hline Cannot explain well & 9 & 8 & 10 & 5 \\
\hline Is unprepared for class & 3 & 5 & 7 & 7 \\
\hline Is unfair in grading & 8 & 9 & 0 & 9 \\
\hline Is disrespectful of students & 22 & 14 & 5 & 13 \\
\hline Doesn't care if students understand & 10 & 12 & 15 & 30 \\
\hline
\end{tabular}

From Table 10 above which condenses information extracted from (I= interviews) and Table 5 (Open-ended question), it can be observed that students' and instructors' perceptions of ineffective teaching coincide with regard to a number of attributes. Both groups describe the ineffective instructor as someone who does not demonstrate respect for his/her students, does not care, is boring, cannot explain the subject matter well, is unprepared for class and is unfair in grading students. Findings from this study indicate that most respondents do indeed hold mirror images of effective/ineffective teaching traits. Table 11 below, which compares the characteristics of effective teaching extracted from research question 2 alongside the results of the ineffective instructor revealed from the interviews and open-ended question discussion, suggest that at least to the population sampled in the selected universities, Ethiopia, there is agreement that study participants do view the two extremes as polar images of each other

The first descriptor of the ineffective instructor to emerge from Table 11 below is disrespectful of students. This finding is particularly interesting for three reasons. First, it represents a very close match in that it appeared with nearly the same frequency in both students' and instructor's data from the open-ended question (Table 5). Second, supportive evidence is provided for researcher earlier argument in favour of the mixed-methodology approach to the questionnaire instrument wherein it was claimed that unforeseen and beneficial results can often be revealed by the use of qualitative methods. Third, it was indeed an unexpected result since the researcher had not anticipated that lack of respect would be an issue raised by students in answering the open-ended question, especially where this study was conducted. Previous research on teaching effective has established caring as an important factor in distinguishing between effective and ineffective teaching. "Is concerned with, and is friendly to ..." have been reported by other authors as an essential personality component (Saafin, 2005; Walls et al., 2002; Beishuizen et al., 2001; Miller et al., 2001; Raymond, 2001; Witcher et al., 2001). Caring therefore appears to be an important quality of effective instructors judging from the aforementioned studies which were conducted around the globe, and from the consistency of responses from two population groups gathered in this study.

Table 11. A comparison of effective and ineffective teaching characteristics

\begin{tabular}{|c|c|}
\hline $\begin{array}{c}\text { Effective instructors (Results of } \\
\text { research question 2) }\end{array}$ & $\begin{array}{c}\text { Ineffective instructors (Results } \\
\text { of research question 3) }\end{array}$ \\
\hline Are respectful of their students & Are disrespectful of students \\
\hline $\begin{array}{c}\text { Care about students succeeding in } \\
\text { their course }\end{array}$ & $\begin{array}{c}\text { Don't care if students } \\
\text { understand }\end{array}$ \\
\hline Make classes interesting & Are boring \\
\hline $\begin{array}{c}\text { Make difficult subjects easy to } \\
\text { learn }\end{array}$ & Cannot explain well \\
\hline $\begin{array}{c}\text { Are always well prepared and } \\
\text { organized }\end{array}$ & Are unprepared for class \\
\hline Are fair in grading and evaluating \\
student work
\end{tabular}

Note: personality measures are highlighted in italicized bold font

A third attribute that was used by study respondents to elucidate what differentiates an effective from an ineffective instructor is the characteristic of being boring. From the excerpts below extracted from both students and instructors, it becomes clear that an instructor's effort at making the subject come alive is an attribute the ineffective instructor either does not possess or does not attempt to cultivate. Interestingly, from the comments taken from the open-ended question, the common thread that emerged is that lecturing without involving students was used to paint a rather grim but succinct picture of the ineffective instructor. One common depiction of the ineffective instructor that surfaced throughout the interviews of students and instructors was the inability of being able to explain a complex topic simply through the use of a lot of good examples.

To sum up, according to this study's respondents, ineffective instructors are: disrespectful of students, do not care, are boring, cannot explain topics well, are unprepared for class and are unfair with their grading. What has resulted from examining the characteristics of ineffective instructors has produced mirror images of six of the nine traits that were considered predominant effective teaching measure by the same sample population. Four of the six personality items and two of the three ability traits are addressed. The missing ability characteristic encourages students'questions and discussion, however, could arguably be considered the opposite of the second highest ineffective instructor characteristic to emerge as one who doesn't care if students understand. Similarly, the first personality trait that did not have a direct mirror image in wording (show that they really like the subject they teach) could be countered by two ineffective instructor descriptors as is only interested in money, not teaching, and, is boring. It can be observed that from the transcribed interviews of study respondents, $54 \%$ of the traits mentioned by instructor and student respondents were attributed to personality measures while the remaining $46 \%$ were categorized as ability, indicating that when verbally discussing effective teaching 
traits, respondents in this study slightly favoured personality traits. Of the two comparative measures, personality traits were indicated to be more dominant than ability characteristics when both instructor and student respondents described the characteristics of the effective instructor in the open-ended question (Table 2). Out of the 46 attributes which were synthesized, $71 \%$ were classified as personality characteristics while ability characteristics occupied the remaining $29 \%$ of the total characteristics extracted from the questionnaire.

What can be observed from Table 12 is that six of the top ten characteristics used in the literature to describe effective quality teaching in the opinions of students and instructors across many diverse cultures and of various age and status rankings are personality traits. Additionally, the first five highest ranked traits on this list are personality traits. Furthermore, in other studies concerned with teaching excellence, researchers have reported that respondents (both instructors and students) tend to focus on personality factors more prominently than on ability factors, irrespective of level, age, nationality, and academic discipline (Walls et al.,
2002). Consistency in the higher importance placed on personality traits arising from the questionnaire results, transcribed interviews, the open-ended questions, and in the literature has been demonstrated.

Research question four: To what extent do mediating factors such as academic discipline and participants' gender have an effect on the portrait of the effective instructor?

To answer this question, Chi-square test for association at the significant level $(\alpha=0.05)$ was used. Only items of significant association (less than 0.05 ) are presented in the tables that follow. Significant association can be interpreted as major disagreement on the level of importance associated amongst the two population groups as to how they rated the 25 questionnaire items on a four-point scale of not important (NI) to very important (VI). Personality and ability measures are discussed independently in what follows. Table 13 below show two significant associations resulting from Chi-square analysis of the 11 questionnaire items categorized as personality traits of excellent instructors.

Table 12. Counts of authors who mentioned a specific ability or personality characteristic in the literature review

\begin{tabular}{|c|c|c|}
\hline $\begin{array}{c}\text { Number of authors who } \\
\text { mentioned this }\end{array}$ & Trait & $\begin{array}{c}\text { Trait Ability (A) or } \\
\text { Personality (P) }\end{array}$ \\
\hline 14 & Is enthusiastic for subject/towards teaching & $P$ \\
\hline 14 & Is available to help students & $P$ \\
\hline 13 & Is concerned with, is friendly to, and respects students & $P$ \\
\hline 13 & Is open to students' opinions, ideas and discussion & $P$ \\
\hline 11 & Stimulates interest in the course/subject & $P$ \\
\hline 11 & Is prepared/organized & $\mathrm{A}$ \\
\hline 10 & Is knowledgeable of subject & $\mathrm{A}$ \\
\hline 10 & Explains using simple terms & $\mathrm{A}$ \\
\hline 10 & Encourages students to think critically & $\mathrm{A}$ \\
\hline 9 & Is sensitive to and concerned with class level and progress & $\mathrm{P}$ \\
\hline 9 & Is fair and impartial in marking/evaluating students & $P$ \\
\hline
\end{tabular}

Table 13. Chi-square test for association between the academic discipline and importance at significant level $(\alpha=0.05)$ on the personality characteristics measure

\begin{tabular}{|c|c|c|c|c|c|c|c|c|c|}
\hline \multirow{3}{*}{$\begin{array}{c}\text { Academic Value } \\
\text { Discipline* }\end{array}$} & \multicolumn{8}{|c|}{ Importance Level } & \multirow{3}{*}{$\begin{array}{c}\text { Chi Value } \\
\text { Sig. }\end{array}$} \\
\hline & \multicolumn{2}{|c|}{$\begin{array}{c}\text { Not } \\
\text { Important }\end{array}$} & \multicolumn{2}{|c|}{$\begin{array}{l}\text { Somewhat } \\
\text { Important }\end{array}$} & \multicolumn{2}{|c|}{ Important } & \multicolumn{2}{|c|}{ Very Important } & \\
\hline & $\mathrm{N}$ & $\%$ & $\mathrm{~N}$ & $\%$ & $\mathrm{~N}$ & $\%$ & $\mathrm{~N}$ & $\%$ & \\
\hline \multicolumn{10}{|c|}{$\ldots$... use humour in the classroom. } \\
\hline Engineering instructors & 0 & 0.0 & 7 & 19.4 & 34 & 53.1 & 23 & 35.9 & 19.736 \\
\hline Engineering students & 2 & 2.9 & 23 & 33.3 & 23 & 33.3 & 21 & 30.4 & \\
\hline \multicolumn{10}{|c|}{.... are friendly to students. } \\
\hline Engineering instructors & 0 & 0.0 & 9 & 14.1 & 23 & 35.9 & 32 & 46.4 & 26.495 \\
\hline Engineering students & 2 & 2.9 & 4 & 5.8 & 12 & 17.4 & 51 & 73.9 & \\
\hline \multicolumn{10}{|c|}{$\ldots$... are fair in grading and evaluating student work. } \\
\hline Engineering instructors & 0 & 0.0 & 0 & 0.0 & 7 & 10.9 & 57 & 89.1 & 19.389 \\
\hline Engineering students & 1 & 1.4 & 7 & 10.1 & 20 & 29.0 & 41 & 59.4 & \\
\hline \multicolumn{10}{|c|}{$\ldots$ have a unique teaching style. } \\
\hline Engineering instructors & 25 & 39.1 & 24 & 37.5 & 13 & 20.3 & 2 & 3.1 & 56.000 \\
\hline Engineering students & 4 & 5.8 & 12 & 17.4 & 28 & 40.6 & 25 & 36.2 & \\
\hline
\end{tabular}


Table 14. Chi-square test for association between the academic discipline and importance at significant level $(\alpha=0.05)$ on the ability characteristics measure

\begin{tabular}{|c|c|c|c|c|c|c|c|c|c|}
\hline \multirow{3}{*}{$\begin{array}{l}\text { Academic Value } \\
\text { Discipline* }\end{array}$} & \multicolumn{8}{|c|}{ Importance Level } & \multirow{3}{*}{$\begin{array}{c}\text { Chi Value } \\
\text { Sig. }\end{array}$} \\
\hline & \multicolumn{2}{|c|}{$\begin{array}{c}\text { Not } \\
\text { Important }\end{array}$} & \multicolumn{2}{|c|}{$\begin{array}{l}\text { Somewhat } \\
\text { Important }\end{array}$} & \multicolumn{2}{|c|}{ Important } & \multicolumn{2}{|c|}{ Very Important } & \\
\hline & $\mathrm{N}$ & $\%$ & $\mathrm{~N}$ & $\%$ & $\mathrm{~N}$ & $\%$ & $\mathrm{~N}$ & $\%$ & \\
\hline \multicolumn{10}{|c|}{... give many quizzes and tests. } \\
\hline Engineering instructors & 13 & 20.3 & 32 & 50.0 & 18 & 28.1 & 1 & 1.6 & 19.573 \\
\hline Engineering students & 6 & 8.7 & 27 & 39.1 & 28 & 40.6 & 8 & 11.6 & \\
\hline \multicolumn{10}{|c|}{... encourage students' questions and discussion. } \\
\hline Engineering instructors & 0 & 0.0 & 0 & 0.0 & 8 & 12.5 & 56 & 87.5 & 24.434 \\
\hline Engineering students & 2 & 2.9 & 4 & 5.8 & 25 & 36.2 & 38 & 55.1 & \\
\hline \multicolumn{10}{|c|}{... use the latest computer technology in their teaching. } \\
\hline Engineering instructors & 16 & 25.0 & 25 & 39.1 & 18 & 28.1 & 5 & 7.8 & 18.562 \\
\hline Engineering students & 6 & 8.7 & 20 & 29.0 & 23 & 33.3 & 20 & 29.0 & \\
\hline \multicolumn{10}{|c|}{... lecture (talk) for the entire class period. } \\
\hline Engineering instructors & 60 & 93.8 & 1 & 1.6 & 3 & 4.7 & 0 & 0.0 & 71.749 \\
\hline Engineering students & 15 & 21.7 & 26 & 37.7 & 26 & 37.7 & 2 & 2.9 & \\
\hline \multicolumn{10}{|c|}{... require students to think critically. } \\
\hline Engineering instructors & 0 & 0.0 & 1 & 1.6 & 21 & 32.8 & 42 & 65.6 & 22.386 \\
\hline Engineering students & 2 & 2.9 & 8 & 11.6 & 35 & 50.7 & 24 & 34.8 & \\
\hline \multicolumn{10}{|c|}{ have many years of teaching experience. } \\
\hline Engineering instructors & 22 & 34.4 & 33 & 51.6 & 8 & 12.5 & 1 & 1.6 & 28.189 \\
\hline Engineering students & 12 & 17.4 & 26 & 37.7 & 15 & 21.7 & 16 & 23.2 & \\
\hline \multicolumn{10}{|c|}{$\ldots$ assign a lot of homework. } \\
\hline Engineering instructors & 23 & 35.9 & 27 & 42.2 & 13 & 20.3 & 1 & 1.6 & 21.130 \\
\hline Engineering students & 9 & 13.0 & 33 & 47.8 & 15 & 21.7 & 2 & 2.9 & \\
\hline
\end{tabular}

Item 4, "use humour in the classroom", reveals that amongst the sample population groups, differences existed between students' and instructor's opinions on the use of humour in the classroom. Engineering instructors in particular rated this personality trait as either important or as very important. Engineering students' low rating of the use of humour in the classroom perhaps reflects their inadequacy in understanding humour conducted. In order to understand humour, a high level of the language as well as advanced cultural awareness is required; both are skills the Engineering students acquire in the intensive program. Hence, this study indicated that a tendency to utilize humour as an appropriate means to stimulate interest in students or to bring their scientific topics to life. The use of appropriate humour in the classroom, therefore, can be interpreted from this study's findings as an indicator of effective teaching. The second personality item to result in significant association, questionnaire item 6, "are friendly to students" was most likely caused by two student participants who claimed that friendliness of instructor was not an important trait of effective teaching. This anomaly occurring with a small sample size in all probability skewed the results since the majority of all respondent groups and subgroups clearly indicated that being friendly to students was an important or very important trait that should be exhibited by effective instructors. Questionnaire item 20, "are fair in grading and evaluating student work" indicated a disparity between instructors and students. Table 14 above illustrates significant associations resulting from Chi-square analysis of the 14 questionnaire items categorized as ability traits of effective instructors.

As indicated in Table14 above, seven $(50 \%)$ of the 14 ability traits indicate a significant association. Item 3, "give many quizzes and tests" was considered a more important ability characteristic to student respondents than it did to the instructor respondents as we have seen earlier in this discussion. Engineering students indicated that they prefer frequent testing. One possible explanation for this could be that Engineering students are tested frequently by their instructors not only to give them practice in taking tests, but also to help them get accustomed to studying daily as opposed to cramming the night before the exam occurs. In addition, Engineering instructors tend to test their students weekly as a means to review and reinforce materials taught earlier, and to help this knowledge transfer to students' long-term memory. Item 5, “encourage students' questions 
and discussion", produced a similar of opinion between student and instructor respondents. Both students and instructors rated this trait as either an important or very important characteristic of effective teaching, some students on the other hand rated this trait as only somewhat important or as not important. One possible explanation for this difference could be that some classes are generally delivered in huge lecture halls with large numbers of students who become passive, note-taking learners, as opposed to other classes which are purposely restricted to smaller numbers and where students are engaged in twoway instruction as a part of their Engineering skills development. Instructors considered questionnaire item 11, the ability "use the latest computer technology in their teaching" to be a less important determinant of effective teaching than did students. A large number of students rated the use of computer technology much higher than did their instructors. Saafin's (2005:132) student respondents also expressed the view that the use of computer technology in teaching Engineering assisted the instructors to be more effective. He argued that students' motivation for learning was enhanced when the students were given the opportunity to "... go to the computer labs and use computers ..." to learn new materials. One plausible explanation for this difference in view could be that students are more attuned to technological advancements than their instructors, see the use of computer programs as fun and entertaining, and would therefore like to see this technology being put to more use in the classrooms to help them assimilate their materials.

Engineering instructors highly agreed that it was not an indicator of effective teaching if one were to "lecture (talk) for the entire class period" (Table 14), while some students tended to rate lecturing as slightly more important. The finding that $37.7 \%$ of the Engineering students rated lecturing as important is surprising, since Engineering instructors minimize the use of lecturing techniques and instead encourage two-way communication with their students as a means of enabling students to practice what they have learned in the classroom. There are two possible explanations for this finding; either the Engineering students did not fully comprehend the question item, despite the re-designing attempts, or the students are inexperienced with this method of instruction and are anticipating with excitement entering into their majors where they believe lecturing is how higher education is conducted.
Instructors rated the ability "require students to think critically" (Table 14) as important or very important, though surprisingly one instructor rated thinking outside of the box as only somewhat important. Another divergence appears to be caused by students who rated this trait as not important. One explanation could be that the Engineering student did not understand the question; is it also possible that students who rated the development of critical thinking as not important were not accustomed to critiquing anything their instructors told them while attending their formative years in university. A contradiction occurred on the ratings of item 21 (Table 14), "have many years of teaching experience", with no agreement on one importance level indicated. What are interesting with these results are the difference in opinion between students and instructors. Teaching experience and age appear to have a lower priority with these study participants.

Table 15 below indicates that female respondents rated the importance of making classes interesting as less important than did their male counterparts. One explanation for this could be that the female students are more engaged with their learning, which helps them to be more selfmotivated than males, thus requiring less entertainment in the classroom to maintain attention to what the instructor is striving to offer them.

This differs from Donaldson and Flannery in Walls et al. (2002), who reported that female student respondents rated instructor's flexibility and acting as a good role model more important than did the male students while Saafin(2005:2226) discovered "student centeredness" to be more important to the female student respondents. Moreover, Saafin “... found no significant differences between the perspectives of males and females on effective teaching". This is consistent with the study conducted by Fernandez \& Mateo in Saafin's (2005) in Spain where no significant differences between male and female students were observed. Hence, even though the present study revealed one uniquely significant difference between female and male student opinions on the trait "makes classes interesting", further research could be conducted on larger sample sizes in order to determine if differences of opinion between male and female students in the different universities.

What follows next is a summary of the findings related to the literature and to the current investigation, conclusions and recommendations arising from this research.

Table 15. Chi-square test for association between the respondent gender and importance at significant level $(\alpha=0.05)$ on the personality characteristics measure

\begin{tabular}{|c|c|c|c|c|c|c|c|c|c|}
\hline \multirow{3}{*}{$\begin{array}{c}\text { Academic Value } \\
\text { Discipline* }\end{array}$} & \multicolumn{8}{|c|}{ Importance Level } & \multirow{3}{*}{$\begin{array}{l}\text { Chi Value } \\
\text { Sig. }\end{array}$} \\
\hline & \multicolumn{2}{|c|}{$\begin{array}{c}\text { Not } \\
\text { Important } \\
\end{array}$} & \multicolumn{2}{|c|}{$\begin{array}{l}\text { Somewhat } \\
\text { Important }\end{array}$} & \multicolumn{2}{|c|}{ Important } & \multicolumn{2}{|c|}{ Very Important } & \\
\hline & $\mathrm{N}$ & $\%$ & $\mathrm{~N}$ & $\%$ & $\mathrm{~N}$ & $\%$ & $\mathrm{~N}$ & $\%$ & \\
\hline \multicolumn{9}{|c|}{$1 . .$. make classes interesting. } & \\
\hline Male & 0 & 0.0 & 0 & 0.0 & 19 & 21.1 & 71 & 78.9 & 8.787 \\
\hline Female & 1 & 2.3 & 1 & 2.3 & 16 & 37.2 & 25 & 58.1 & .032 \\
\hline
\end{tabular}




\section{Conclusions}

Classification by personality and ability as a commonly accepted method for examining effective teaching characteristics since respondents tend to categorize effective teaching using these two dimensions, and that the personality measures are the higher ranked of the two categories. Important personality traits used to describe effective teaching are the following: is enthusiastic towards teaching the subject, is available to students, respects and is friendly to students, is open to students' ideas and opinions, stimulates interest in the topic, is sensitive and concerned with students' progress and is objective in evaluating students. Predominant ability attributes used to describe effective instructors are being well prepared and organized, possessing subject knowledge, being able to explain difficult subjects using simple terms, and encouraging students to think critically.

From the current study, since respondents indicated no objection to the use of the personality and ability descriptors used in the questionnaire instrument, it can be argued that students and instructors do tend to categorize effective teaching characteristics under personality and ability traits, and thus consistency with the literature is demonstrated by this study's respondents. The personality view is essentially a moral view of human nature which espouses an array of humanistic values which make for effective relationships in society. Some argue that "personality" traits are innate, such as those found in leaders and effective instructors, but would also acknowledge that these traits can be learned and refined through instructor training programs, professional development and continuous life-long learning. The ability view, in contrast, is predicated on objective evidence that there are certain identifiable characteristics which are effective in certain situations, such as in the classroom. Ability attributes or skills are based upon the scientific view that humans have certain cognitive, measurable attributes. Findings from this study (Research Question 4) indicate that study respondents, similar to those examined in the literature review, have used descriptors of effective teaching characteristics more focused on the personality view. However, the fact that ability attributes run closely behind personality traits remind us that both are crucial and are not mutually exclusive to the difficult task of describing the effective instructor. The findings of this study support the results of previous studies on teaching effectiveness which demonstrate that many traits or practices are common, regardless of culture, age, and/or academic discipline. It also supports the literature findings of relatively high correlations between students and instructors in what they appreciate in instructors and that student opinions are of value.

Results from research Question one which attempted to capture predominant characteristics of effective instructors have revealed that all of the predominant personality and ability measures used by this study's respondents to describe effective teaching coincide with principal characteristics revealed in the literature review. Common personality characteristics of effective teaching therefore appear to be: demonstrating respect to students, delivering interesting classes, caring about students' welfare, exhibiting a love for the subject being taught, and being friendly to students. Common ability attributes of effective teaching are demonstrated by educators who encourage two-way communication with students, are organized and well-prepared, and present topics in ways that students can relate to and easily understand.

Research questions two and three examined the degree to which student perceptions of effective and ineffective instructors are similar to instructors' perceptions. Only two personality traits appear to have raised significant differences of opinion between the study's two population groups. Having a unique teaching style is perhaps being expressed by new, inexperienced students who are expecting to be entertained in the classroom or, conversely, in fact do learn more effectively from instructors who vary their instructional delivery. This leads us to the suggestion that instructors who employ a variety of methods of communication in the classroom may concurrently improve knowledge transfer and secure higher student ratings on their assessments. All instructors agreed that lecturing was not an indicator of effective teaching. Expressing the expectation of students to interact in two-way dialogue by the instructors at their university where the survey was conducted was encouraging to see, since as it has learned above, lecturing is not viewed as a favourable method of effective teaching according to both the literature results and this study's respondents. The lower rating of this trait by students is probably once again an example of students' inexperience with this manner of communication, and with their expectation or misconception that university classes are of the lecture format. Both students and instructors regarded the affective quality to treat learners with respect and caring as very important. The participating instructors' and students' perceptions also correspond with regard to making classes interesting, caring about their students' success, demonstrating a love for teaching and being friendly. In addition to the five personality characteristics listed above, three ability attributes were also stressed as being very important to all participants: encouraging students' questions, being well prepared and organized, and having a knack for making difficult subjects understandable. Thus, according to these study participants, both skills and affective factors are necessary virtues to paint a portrait of the effective university instructor. As we have seen above, all of these personality and ability factors used to describe effective/excellent teaching were highly compatible with the literature reviewed for this study.

Conversely, instructors rated as more important than students the ability to think critically, being fair in grading, encouraging students' questions and discussion, and 
expecting students to become independent learners. This is a potentially important finding and it is tempting to conclude that instructors' judgments of effectiveness are founded on strong pedagogical principles and the acquisition of a more global view of education learned in their professional development programs. However, it is also possible that instructors respondents in this study place more emphasis on teaching characteristics which are included in their annual evaluations, or on those they believe are expected of them to deliver. Once again student inexperience or unfamiliarity with this concept may have caused this difference of opinion to appear.

According to this study's respondents, ineffective instructors are: disrespectful of students, do not care, are boring, cannot explain topics well, are unprepared for class and are unfair with their grading. What has resulted from examining the characteristics of ineffective instructors has produced mirror images of most of the traits that were considered predominant effective teaching measure by the same sample population. This finding helps to bring into question Walls et al.'s (2002) claim that ineffective traits are not replicas of effective ones, and also provides validation of the present study methodology, purposely designed to measure effective teaching traits using an alternative method. However, comparable to the Walls etal. study, the present findings also indicate that students and instructors hold similar perceptions of what characterizes an ineffective instructor. Research Question five was included in this study in an attempt to determine if mediating factors such as academic discipline and gender would impact respondents' portrait of the effective instructor. One conflict of opinion occurred between students and instructors in their opinions of the value of teaching experience and age of the instructors. Students ranked this ability trait much higher than did instructors, suggesting that cultural values may still play an important part in the instructor-student relationship. Finally, a gender difference appeared over the issue of valuing instructors who demonstrate the ability to make classes interesting: female respondents did not view this to be as important as did their male counterparts.

Finally, the findings of this study conducted in the selective universities, are consistent with past research conducted not only in a similar setting, but also with research conducted at various locations around the globe. Findings support a widespread view that certain personality and ability traits are critical to effective teaching. Both personality and ability characteristics are used by respondents in describing effective and ineffective teaching, with personality traits appearing to be the more important of the two. In addition, a high degree of concurrence exists between what both instructors and students consider to be effective teaching. Most instructor respondents appear to be aware of their students' expectations of requisite ingredients for teaching effectiveness/excellence. Furthermore, it is clear those students from different disciplines use similar measuring criteria to evaluate their instructors, and that these criteria, as mentioned above, are consistent with those used by their instructors. Some evidence has also been uncovered to support the view that ineffective teaching is the mirror image of effective teaching.

\section{Educational Implications}

Based on the findings of this study and the conclusions drawn from them, the following implications on policy and practice are identified:

1. Effective teaching and instructors' characteristics in higher education in Ethiopia needs to recognise instructors and students as an important stakeholder in the educational process as a whole and in the practices of teaching and learning at universities in particular. The decisions-national or institutional- on how instructors and students should be involved and what contributions they can make in the valuation of teaching. Findings also show that Ethiopia students' are capable of identifying and separating various dimensions of quality and relevance of effective teaching, which is evidence that their ratings are not overly dominated or determined by a single factor, personal or otherwise, but by a group of factors which share much in common with the factors identified by other higher education students around the world.

2. Mandates and standards prescribing best practices in effective teaching and learning in Ethiopia's higher education should be grounded on sound understanding of Ethiopian instructors' and students' educational upbringing in college and university education. This is not to say that these mandates and standards ought to cement or condone the status quo in public and private schools' teaching approaches, but rather to recognise that some of the teaching strategies and methods students are used to may be in strong conflict with the best practices in teaching emphasised in the country's quality assurance system for higher education.

3. Addressing the gap between the skills emphasised by colleges and universties expectations is a national dilemma, which requires long term strategies and immense efforts on the part of policy makers and policy implementers in higher education. The newly established quality and relevance of teaching practice in higher education should not underestimate the implications of this gap, nor should it assume that effective teaching practice and instructors characteristics in higher education can be fully and successfully implemented irrespective of the educational policy.

4. Identifying students' and instructors' characteristics and views of teaching and best practices in college and university classroom is an important pathway to addressing certain aspects of the problem highlighted in chapter one. The findings from such investigations, coupled with proper induction programs for instructors and students, can assist effective teaching and instructors characteristics achieve their goals and meet their benchmarks without triggering conflicts in college and university classrooms. 
5. College and university administrators and instructors should be ready to face the reality that students' perceptions of effective teaching, whether systematic or informal, may be influenced by a number of factors that may be considered irrelevant to effective teaching practices, such instructor's qualification, course difficulty, course type or other factors. Care should be taken, however, in interpreting these factors as biases to students' ratings, as there could be other underlying variables that may influence students' ratings which are not easy to detect from teacher overall ratings alone. These may stem from the nature of the course itself or even from teaching behaviours which are not covered by the rating instrument.

\section{Recommendations}

Based on the findings of this study, the following recommendations are made. First, induction programs for new instructors entering university, particularly engineering departments in the universities of Ethiopia should include a discussion of the impact of established, objective and unalterable evaluation and grading procedures on students who might be unfamiliar with this approach. Vital communications such as this could avoid potential conflict with students receiving their mid- or final semester grades, and thus improve classroom relationships.

Second, if more instructors can be made aware that students' perceptions of effective teaching are similar to their own, and are considered to be valid by researchers countrywide, instructors could benefit from considering rather than rejecting student feedback when evaluating their teaching performance. Specific to teaching implications, awareness of the similarity in how students and instructors view effective teaching may help instructors in various disciplines, to consider their students' specific needs and help them to amend their teaching styles or methods accordingly to better serve their students. Making public the results of this research project could have a positive and practical effect on practicing as well as prospective instructors as they prepare to meet the challenges of effective teaching and provide them with notions of how to improve their teaching.

Since this study was conducted in what might be referred to as selected universities culture, it is hoped that this undertaking will serve as a resource for any instructor from another universities striving to adapt to the needs of students in the Ethiopia. It is also hoped that this study will help other researchers wishing to further explore Ethiopian schools and colleges students' perceptions of the effective/ineffective instructor. There are a number of implications raised by this study which could benefit administrators and instructor training program developers.

First, this study could provide university policy makers with an applicable list of effective teaching characteristics to help them design appropriate, sensitive and reliable instruments to evaluate and encourage teaching effectiveness of their instructors. Since both student and instructor perspectives have been ranked in order of importance, a valid evaluation form of teaching effectiveness used by students and administrators to evaluate their instructors could be developed. If the same form is used by both administration and students to rate instructors, might more seriously consider student feedback, administrators could become more enlightened as to the constantly evolving demands of the classroom environment, and thus validity of the evaluation instrument could be ensured.

Second, attributes of what constitutes effective/excellent teaching in the eyes of the students specific to the universities where this study was conducted could become a valuable part of recruitment and in-service offerings. Providing such information and training to new and/or adjunct instructors as well as to veteran instructors with consistently low student ratings could contribute to student satisfaction and improved learning, better instructors' performance, institute reputation for the provision of service excellence, and improved student retention.

Third, this study may impart valuable information to teacher training and program curriculum development specialists by providing them with the results of university students' and instructors' perspectives in universities environment to guide them in creating more effective and culturally sensitive training programs. Equally important, if the attributes of what is required to be effective instructors are made available to candidates considering the teaching profession prior to their commitment to the program, frustration, loss of self-esteem and waste of time and money could be reduced. Similarly, attrition rates from teacher training programs could be reduced if job performance criteria were made transparent to potential teachers prior to their commitment to the program.

Fourth, results of this study could be used in induction programs aimed at developing those who have entered the field of teaching via alternative routes, rather than through teacher education certification. Proper preparation for doctoral candidates entering the classroom environment as an instructor for the first time could include not only what constitutes effective teaching and as well as instruction and training on how to aspire to those characteristics, but also create an awareness that student perceptions are similar to instructor perceptions and are considered in research to be valid. In addition, the results of this study could also be used to develop workshops to disseminate information on what constitutes effective teaching throughout the Ethiopian universities and made available to all who opted to attend.

Finally, results of this study could be used in student induction programs to help new students to the university setting understand what is expected of them, how classes are conducted, and how instructors from other cultures may have different expectations and ways of dealing with students. 


\section{REFERENCES}

[1] Barnes BD, Lock. G. (2010). The attributes of effective lecturers of English as a foreign language as perceived by students in a Korean University. Australian Journal ofTeacher Education, 35(1): 139-152.

[2] Beishuizen, J. J., Hof, E., Putten, C. M., Bouwmeester, S., \& Asscher, J. J. (2001). Students' and teachers' cognitions about good teachers. British Journal of Educational Psychology, 71(2),

[3] Berk, R.A (2005). Survey of 12 Strategies To Measure Teaching Effectiveness. International Journal of Teaching and Learning in Higher Education. 17(1), 48-62.

[4] Biggs, J. (2003). Learning to teach in higher education. Maidenhead, ENG: Society for Research into Higher Education.

[5] Borich, G. D. (2000). Effective teaching methods. New Jersey: Prentice-Hall.

[6] Cheng, Y.C., Mok, M.C. \& Tsui, K.T. (Eds.). (2001). Teaching Effectiveness and Teacher Development: Towards a New Knowledge Base. Hong Kong: Hong Kong Institute ofEducation and Kluwer Academic Publishers.

[7] Creswell, J.W. (2009). Research design: A qualitative, quantitative, and mixed method approaches.Third Edition. Sage Publications. Inc.

[8] Day, C. (2004). A Passion for Teaching. London: Routledge
Falmer.

[9] Hay McBer (2000). Research into Teacher Effectiveness: A Model of Teacher Effectiveness. A report by Hay McBer to the Department of Education and Employment, United Kingdom.

[10] Hiebert, J. \& Grouws, D. (2007). The Effects of Classroom Mathematics Teaching on Students' Learning. In Lester, F.K., Second Handbook of Research on Mathematics Teaching and Learning (371-404). New York: MacMillan

[11] Oredbeyen, O. (2010). Students' perceptions of effective teaching and effective lecturer characteristics at the University of Ibadan, Nigeria. Pakistan Journal ofSocial Sciences, 7(2): 62-69.

[12] Raymond, S.M. (2001). Excellent teaching: perceptions of Arab, Chinese and Canadian students. In Voices of Arabia, Chapter 2: 17-30, University of Sheffield, U.K.

[13] Saafin, S.M. (2005). An Investigation into Students' Perceptions of Effective EFL Teachers at University Level. An unpublished thesis submitted in partialsatisfaction of the requirement for the degree of Doctor of Philosophy inEducation, University of Exeter, Exeter, United Kingdom.

[14] Walls, R.T., Nardi, A. H., Minden, A.M., \& Hoffman, N. (2002). The characteristics of effective and ineffective teachers. Teacher Educational Quarterly, Winter, 29(1), 3948.

[15] Witcher, A.E., Onwuegbuzie, A.J., \& Minor, L.C. (2001). Characteristics of effective teachers: Perceptions of preservice teachers. Research in the Schools, 8(2), 45-57. 